\title{
Communities making social change from below. Social innovation and democratic leadership in two disenfranchised neighbourhoods in Barcelona.
}

\author{
Santiago Eizaguirre \\ RG - Creativity, Innovation and Urban Transformation (CRIT) \\ Department of Sociology. University of Barcelona \\ santieizaguirre@ub.edu
}

Marc Parés

RG - Urban Governance, Commons, Internet and Social Innovation (URGOCIS) Institute for Government and Public Policies (IGOP) - Universitat Autònoma de Barcelona. marc.pares@uab.cat

Communities making social change from below. Social innovation and democratic leadership in two Barcelona's disenfranchised neighbourhoods.

\begin{abstract}
Drawing upon 4 initiatives of social innovation embedded in two disenfranchised neighbourhoods: Nou Barris Nord and Sants in Barcelona (Spain), we illustrate different ways in which bottom-up processes can contribute to neighbourhood resilience. The paper explores the nature of social change by bringing together systemic approaches to social innovation and relational theories of collective leadership. In this vein, it is argued that both contextual neighbourhood features and collective leadership practices dialectically explain not only how and why social innovation initiatives emerge but also their social impact in terms of effectiveness and scalability.
\end{abstract}

Keywords: social innovation, democratic leadership, bottom-linked governance, neighbourhood resilience

\section{Introduction}

The 2007 financial crash brought with it a new stage of the neoliberal project: public bailouts and austerity regimes embarked upon by assorted states and international organizations to save the global financial system (Lowndes \& Pratchett 2012; Davies \& Pill 2012; Peck 2012; Swyngedouw 2015). A huge wave of privatization and cuts was implemented across western countries, especially in Southern Europe, retrenching the role of the public sector. This opened up new opportunities for markets but also for social initiatives (Parés et al., 2017a). The second 
phase of modernity - reflexive or liquid modernity (Bauman 1999; Giddens 1999; Beck 1992) definitively evolved into a non-state-centric model in which the state no longer provides the principal means of compensating for market failure.

In Spain, as in other Southern European countries, the recession and subsequent austerity policies brought about dramatic effects in terms of poverty, social exclusion, unemployment, foreclosures and so on (Leon \& Pavolini 2014). However, in 2011 insurgent citizens and incipient urban political movements unsettled the neoliberal status quo and the austerity paradigm noted above (Swyngedouw 2015; Fregonese 2013). The Indignados movement burst in Barcelona, Madrid, and many other Spanish cities and towns. Since then, new forms of urban activism emerge while old social organizations adapt to the new societal context (Gualini et al. 2016; Walliser 2013). Citizens are, increasingly, self-organizing in order to produce innovative solutions to face the collective problems that governments are failing to solve in a context of scarcity and austerity policies (Parés et al., 2017b). Where and how do these responses emerge? How are they carried out? What are their impacts?

In this paper we focus on two communities - at neighbourhood level - in Barcelona (Nou Barris Nord and Sants) to better understand how socially innovative processes take place in a context of crisis. We argue that both contextual neighbourhood features and collective leadership practices dialectically explain not only where, how and why social innovation initiatives emerge but also their social impact in terms of effectiveness and scalability.

As we will demonstrate through empirical analysis of four initiatives, context - understood as a varying path-dependent and spatio-temporal configuration of constraints and opportunities shapes how and where social innovation emerges and in what form. We will specially focus on civic capacity, defined as the ability to coalesce governmental and non-governmental actors concerned with collective problems (Stone 2001) or, in other words, the extent to which different sectors of the community act in concert around a matter of community-wide import. Thus, we understand civic capacity as a community resourceand a contextual neighbourhood feature that varies from one neighbourhood to another.

At the same time, however, we argue that we need agency-based explanations in order to comprehend the capacity of socially innovative initiatives to catalyse collective action in particular ways, in specific conjunctures and broader structural contexts. As Moulaert et al. (2016) have already suggested, new avenues for analysing socially innovative initiatives are opened up by understanding social change as a process driven by context-sensitive dialectical relationship between neighbourhood features and collective agency, materialized through discursive practices and mediated by institutions.

More concretely, we will analyse collective agency through leadership practices, understood as collective and meaning-making interventions and patterns of behaviour that make things different from what they were before, fostering social change. Leadership is a unique type of meaning-making process. This is so because the shared agreements that produce leadership are articulated and generated within a community of practice, or a group working to achieve results (Ospina et al., 2012).

In the reminder of this paper, first we briefly introduce our methodological framework and define the concepts we are working with. We then present our two communities in separate sections. In each community we describe the socially innovative initiatives analysed and describe their historical-geographical path-dependencies, leadership practices and impacts. In the last section we relate our analysis to theliterature, reflecting on the strengths and limitations of these initiatives in the context of their respective neighbourhoods. We also suggest some strategies for increasing the effectiveness and scalability of social innovation.

\section{Theory and methods}

Social innovation is usually conceptualized as a way of improving territorial development in disenfranchised neighbourhoods (MacCallum et al. 2009; Moulaert et al. 2010; Van Dyck \& 
Van den Broeck 2013). This approach highlights the importance of context - historical and geographical - and path-dependencies in understanding how socially innovative practices emerge and how they may become processes of social change. However, little attention has been paid to the dynamics by which innovations emerge, how social impact or scalability could be achieved and, finally, how social change could be effectively accomplished through socially innovative responses at the community level. Indeed, the study of leadership, as the agential dimension of change, has been almost entirely absent in studies of social innovation.

This paper combines the analysis of 'neighbourhood features' and 'collective leadership practices' to better understand how communities are facing the effects of economic recession through socially innovative initiatives in Barcelona. To the best of our knowledge, an approach that brings together critical theories of collective leadership and disruptive theories of social innovation is a novel undertaking.

We focus on the impacts that socially innovative initiatives are triggering, defining these impacts in terms of effectiveness and scalability (Parés et al., 2017b). Drawing on Moulaert's et al. (2013) definition of social innovation, we understand effectiveness as the extent to which a socially innovative initiative achieves the desired social transformation with respect to: a) resolving the social problem it set out to address, b) empowering citizens, and c) producing changes in social and power relations.

Scalability, on the other hand, refers to the capacity of a socially innovative initiative to expand or grow by way of either scaling out or scaling up. Scaling out refers to an initiative engaging more people, being more inclusive and broadly solving the problem it set out to address. Scaling up refers to an initiative expanding up from the local level to a new geographical context beyond the neighbourhood.

Concurrent to new forms of social innovation arising around the world, concepts such as distributed, shared, collaborative and collective leadership have gained currency both in the academic literature (Uhl-Bien \& Ospina 2012) and in the world of practice (Heifetz et al. 2009). These concepts challenge traditional views of leadership and shift attention from formal leaders and their influence on followers to the relational processes that illuminate the contribution of all to constituting leadership in a group, organization or system (Ospina \& El Hadidy 2013; Ospina 2006).

More concretely, in order to assess the inpact of social innovation initiatives we have focus on three sorts of leadership practices (Ospina et al. 2012):

- Unleashing human energies: leadership practices that empower the have-nots, practices that stem from the assumption that knowledge is power.

- Bridging difference: leadership practices that create the conditions to bring divers actors or social groups together and facilitate their joint work while maintaining, appreciating and drawing on their differences.

- Reframing discourse: leadership practices that disrupt established frames, while proposing others that are more congruent with their vision for the future.

Since we thought that contextual historical and geographical neighbourhood features are crucial to better understand these socially innovative initiatives and their impacts, we adopted a comparative embedded case study design focussing on two different neighbourhoods. The effects of the Great Recession have been acutely felt in both neighbourhoods, as as evidenced by the data in Table 1 on average family income. However, while Sants is a more resilient neighbourhood with a dense social fabric and a strong tradition of social activism, Nou Barris Nord is a more vulnerable area with a fragmented social capital and less capacities to cope with the recession effects. 
In each neighbourhood we explored two socially innovative initiatives dealing with the effects of the Great Recession and austerity policies. Our main selection criteria was that initiatives were offering responses to the crisis and cohered with the academic definition of critical and transformative social innovation (Moulaert et al., 2013). In both territories we have analysed an initiative which appeared in a context of crisis, originating after 20082008 (PAH in Sants and $50 \times 20$ in Nou Barris Nord), as well as an initiative emanating from a previously existing association, or from struggles that were taking place before the crisis(Centre Cruilla - Nou Barris Nord and Plataforma Recuperem Can Batlló in Sants).

Data was mainly collected through interviews with key respondents. 15 interviews were carried out in each neighbourhood between November 2015 and January 2016. The people interviewed have been selected in most cases for being representatives of the selected initiatives, but we also interviewed professionals and public managers working on the socio-communitarian dynamization of each neighbourhood, as well as active members of the neighbourhood movement not necessarily linked with the selected initiatives. In addition to the analysis of secondary data sources and published documentation on each one of the case-studies, we have akso drawn on data and results from previous research projects, such as as Barris $i$ Crisi and POLURB ${ }^{1}$..

\section{Nou Barris Nord: solidarity and resistance to cope with crisis effects}

Nou Barris Nord is a segregated and deprived area that has never overcome its vulnerability. It has been hit extremely hard by the effects of the Great Recession. However, to really understand what has happened in the area we should not focus on how the crisis has affected it (unemployment, foreclosures and so on) but on how the area was transformed prior to the crisis. Nou Barris Nord has always been a disenfranchised urban area. Nevertheless, the real estate bubble multiplied its urban segregation as a result of a huge demographic replacement, resulting in the poorest population in Barcelona becoming concentrated in this area. The social fabric of Nou Barris Nord was fragmented and its social capital declined, while civic capacity evolved into a general mistrust and hostility between, on the one hand, neighbourhood associations and, on the other, the City Council.

In this context the emergence of social innovation initiatives is not easy. When initiatives flourish, the lack of coordination and collaboration with public authorities hinders their potential social impact.The lack of commitment by public authorities to local needs has been a historically determinant factor. The endemic scarcity of public services and resources is related with a low civic capacity. Hence, we found few socially innovative initiatives in Nou Barris Nord and, in general terms, they were small initiatives achieving a low social impact. Rather than being transformative initiatives, the social innovation we found was clearly pragmatic, attempting to address concrete problems related to basic social needs. The residents do not have the tools to solve their collective problems autonomously or using power-based models of social change. The socially innovative actors tend to use community development or community building approaches. In essence, they focus onattracting greater public investment and commitment on behalf of public authorities.

However,part of Nou Barris Nord story is one of struggle based on the neighbourhood's tradition of collective action for the mobilisation of resources Neighbours, neighbourhood associations and other community-based organizations have clearly responded to recession effects through solidarity and resistance. The anti-evictions movement is probably the best example of that, but we have also identified many other initiatives. Although there is only a small group of engaged neighbours who are fostering such initiatives, their role is essential not only in mitigating the effects of the recession in the area but also in fostering coexistence and solidarity.

\footnotetext{
${ }^{1}$ The results of these projects have been published in several publications (Blanco \& Leon, 2016; Subirats \& García-Bernardos, 2015)
} 
To exemplify the type of leadership practices emerging there we focused on Centre Cruilla, a non-profit service provider working on youth labour inclusion; and 50x20, an emerging effort of 50 people collecting $€ 20$ per person each month and distributing these resources to communitybased organizations to cope with social emergencies.

\subsection{Centre Cruïlla}

Centre Cruilla is a traditional not-for-profit third sector organization tied to a religious community - the Salesians - operating through the church of Sant Bernat de Claravall. It began during the 1980s as an educational project and has evolved into a second chance schools. Since 1993 it operates as a youth-oriented centre devoted to offer non-curricular educational opportunities to low-income youths. In addition, since 1988 it has also been officially recognised as a service that offers an alternative space for 14 to 18 year olds that have been expelled from or refuse formal education. As the centre has developed, many kinds of social and pre-workforce projects (focused on 18 to 28 year olds) have also been implemented. The centre aims to facilitate employability through chefing courses, entry-level courses in various skilled trades, or promoting the learning of occupational skills. It has also launched courses oriented toward teenagers in order to develop specific skills oriented towards jobs such as sports instruction and leisure-time monitoring.

Centre Cruilla's professionals are highly informed regarding what is happening in the community and the basic needs of the neighbourhood. From 2008 onwards, they clearly identified the youth of Nou Barris Nord as being dramatically hit by the recession due to the blocking of their access to the labour market became . The young people that took part in Centre Cruilla's programs became deprived of opportunities to enter into the labour market upon completion. To address this situation, in 2012 Centre Cruilla launched an innovative program creating a not for profit temporary employment agency.

This experience has been very well received by other centres of the Salesian community working in similar situations in other deprived neighbourhoods. Thus, the initiative is travelling geographically to other communities in a clear process of scaling-up. The diffusion of the tested model of job insertion developed by Centre Cruilla across the network of second-chance schoolcentres of the Salesian community demonstrates the scalability and originality of the project.

It is estimated that around 150 young people per year follow Centre Cruilla's educational activities. With respect to social impact, interviewees stressed the infrastructure developed by the Centre over the years including a set of spacious rooms suitably equipped for implementing educational programmes. A further indicator of social impact that was commonly highlighted was the attention garnered from external sources of investment, such as socially inclusive projects that became interested in the initiative as part of their philanthropic programmes. Finally, the existence of ambitious projects for the future, such as the development of a school-restaurant for culinary students to experiment with modules, also evidences the vitality and social impact of the initiative.

From the outset, the main objective of Centre Cruilla has been working with young people with the aim of fostering youth community development. In addition to its specific work with young people from the community, the Centre Cruilla also plays a central role coordinating Nou Barris Nord's Community Development Plan. The Centre Cruilla has assumed financial management of the subsidy associated with this plan and co-ordinates the staff responsible for its implementation. This leading role reflects the level of professionalization of Centre Cruilla, which is clearly higher than the rest of the neighbourhood's community-based organizations. The Community Development Plan is based on fostering networks among all the stakeholders, neighbours and projects in the area.

Centre Cruilla has a facilitative and collaborative relationship with the rest of projects and community based organizations working in the area. The fact that the Centre is characterized by the professionalization of the actors that are leading the initiative enables it to steer clear of the 
personal conflicts typical of the neighbourhood associations and other community-based organizations which operate on a voluntary basis. Even though some of Centre Cruïlla's social educators live in Nou Barris Nord, most of them do not. What we found among these social workers is the profile of a committed educator, highly engaged and rooted in the neighbourhood, with direct knowledge and a participative attitude with respect to the grassroots movements in the area. Moreover, most of Centre Cruilla's social educators play an important communicative and informative role, not only through Centre Cruilla informal channels but also having an active role in the neighbourhood's social life. Thus, although Centre Cruilla fulfils an important task working with young people through its programs, it also has an important role at the broader community level, networking different stakeholders and having good relations with all of them, including public bodies.

Relationships between Centre Cruilla and public authorities are positive and dynamic. There is a constant communication with the District authorities, which recognize the important role carried out by the Centre. By contrast, from the point of view of the Centre, public authorities in Nou Barris Nord is criticised for the absence of a comprehensive approach to the creation of public policies. The Centre stresses that various municipal governments have acted in the area without having an over-arching perspective, promoting isolated policies resulting from a fragmented approach. The recent application of an urban renewal project has been perceived by the Centre in the same way, arguing that the project has been highly focused on the built environment and has neglected socio-communitarian issues. Even though the Centre is essentially a service provider and adopts a very pragmatic approach, it is also producing a general discourse calling for integrated approaches as well as more specific discourses focused on youth development through both education and labour market opportunities.

The way in which Centre Cruilla lobbies to gain influence on the public administration and its policies is based on the principle that claiming and protesting is always needed to achieve direct effects and public investment in the neighbourhood. One of the main principles invoked to justify the need for essential investment in Nou Barris Nord is the need to achieve equality with the rest of the city of Barcelona with respect to living standards and human development.

\section{$2.2 .50 \times 20$}

In a public meeting held in Ciutat Meridiana in 2009, neighbours from various parts of Nou Barris Nord decided to develop a new initiative to address the growing social emergency faced in the area. Fifty neighbours decided to pay $€ 20$ each month in order to combat the social problems that public authorities were proving unable to solve. 50x20 was, therefore, an informal initiative conceived of as a self-managed and self-organized act of resilience in the face of collective problems. At the same time, however, it was an act of contestation demonstrating that neighbours were being forced to act to take responsibility for a role that public authorities were failing to fulfil.

Fifty people collecting $€ 20$ per person each month inspired the name of the new informal organization: 50x20. The name of the organisation took inspiration from the main activity of having 50 people collecting 20 EUR per person: $50 \times 20$. The initiative is motivated by the terrible effects produced by the crisis in these neighbourhoods, as well as the increased burden placed on neighbourhood associations stepping in to deal with the effects of the crisis in lieu of public bodies.

The main objective of the initiative is to supply a Caja de Resistencia (emergency hardship fund) that serves to give financial support to people in need identified by various actors working in the area. Different kinds of initiatives and organizations contribute to identifying need, from schools to neighbourhood associations. What they have in common is that they have direct day to day contact with the social emergency faced by the community.. Thus, rather than develop the community through housing, business or social programs, 50x20 uses a community building approach, which emphasizes relationships, consensus building and voluntary action. In short, it aims to mobilize community assets. 
In this context, 50x20 is committed to collecting, managing and giving a purpose to the money it gathers. All the money is deposited in a bank account from where it is delivered to neighbourhood social organizations depending on the needs identified in an area. The organizational idea behind the initiative is that the money it can offer to rapidly address family and/or individual needs is always managed by a social organization which first receives the money, meets the demand, and ensures the money is used correctly. In return for the money that is provided, associations taking part in the intiative are encouraged to achieve some sort of socio-educational return for their beneficiaries.

The initiative is led by a five person board, most of them social workers and professionals engaged with the community. It is a self-organized and self-funded initiative carried out by volunteers with high levels of education and professional skills. Even though the initiative is managed in a very horizontal and transparent way, there is a small group of engaged people at the helm . As well as distributing money to social organizations they strengthen links among them, bridging differences at community level.

The area in which 50x20 has offered most support is school activities. During the first five years of the initiative, school dinner subsidies represented more than 60 per cent of the total budget. The subsidies provided by public authorities do not cover the total price of the dinners. As a consequence, many children left school during lunch hours because their families could not afford to cover the cost. Scholarships to attend summer camps have also represented a large part of the money donated by the entity to the schools of the area.

It might be said that the relationship between the initiative and public authorities is a complex and confused. . From 50x20's perspective, it is believed that some actors from the City Council feel threatened by the activities which the group carries out. The fact that $50 \times 20$ acts as an emergency hardship fund for the network of neighbourhood associations is perceived as evidence of public policy failure. However it is not fair to accuse the initiative of promoting a negative vision of public policies; in fact, the role played by $50 \times 20$ remains low profile, and its members refuse to appear in the media. Their priority is to provide resources to the network of associations in the area, reflecting a cooperative and collective leadership that aims to produce some kind of social transformation.

The District administration has recognised 50x20 as an accredited interlocutor. As a result, the district has approached 50x20 to ask it to provide a diagnosis of the social problems in the area. Public authorities have also indicated they are willing to act upon the recommendations made by the association for changes in community policies. However, this proposal has also been refused by 50x20 because they do not feel prepared to act on such a scale, and they do not wish to facilitate the withdrawal of direct state support in an area of high need which has also lacked public resources and services..

50x20 does not renounce expressing opinions regarding how the application of local policies could be improved. For example, 50x20 has criticized the location of a Fab lab project set up in Ciutat Meridiana in 2014, and advocates a more accessible and functional project which would be particularly focused on promoting socially innovative dynamics with the local high-school and upon fostering its specialization in the field of robotics. Another example relates to funds for school dinners; when the public authorities suggested that subsidies were being paid for, 50$\mathrm{x} 20$ provided evidence there remained unmet need. In any case, as their representatives suggest, $50 \times 20$ does not aim to take over public responsibilities; on the contrary it aims to stress the leading role that public authorities ought to assume regarding the challenges in the area. The organisation is thus highly pragmatic because it aims to meet social needs directly whilst also reframing public discourse in favour of comprehensive responses and pressing for local authorities to take responsibility. 
In short, 50x20 offers new, alternative and community-managed solutions to basic social needs in Nou Barris Nord, changing social relations and building community networks. The initiative is small and, rather than working together with the public administrations, it acts as a resistance project, showing that public bodies are not doing all they should in the area. The lack of resources relative to the scale of the problems it aims to tackle have limited the effects of the initiative, and have also prevented expansion. . However, rather than aiming to be a permanent part of the solution, they aim to make the case for greater investment in the area and to pressure public authorities to take greater responsibility for the conditions faced by the community. .

\section{Sants: counter-hegemonic practices in a politicized neighbourhood}

Sants is a traditional working-class neighbourhood, whichhas proven to be less vulnerable to the recession than Nou Barris Nord. Nevertheless, the neighbourhood has become poorer since 2008; unemployment has significantly increased, numbers of small businesses have declined and foreclosures have risen following the crash. This is specially so in the poorer areas of the neighbourhood

Sants' character is that of a small town within a city, and it has retained a strong sense of belonging among its residents and its social organizations. The area has accumulated experience of numerous historical struggles with an extremely high level of political activism being developed there. Several generations of activists now overlap in Sants. The achievements of these generations, and the social learning stemming from them, have endured while, at the same time, a diverse mix of social organizations not only coexist but also tend to collaborate in order to campaign for neighbourhood improvements or jointly develop community-based activities.

Socially innovative initiatives readily emerge in a context which affords them the potential to be effective and to grow in scale. Social innovation in Sants is not something new. It is not a response to the post-recession situation in the area, but rather the result of a tradition of bottom-up collective action which is historically rooted, diverse and politicized. Thus, in Sants we can see a tradition of co-operativism, self-management and self-organizing. This is a tradition of alternative action, that flourishes in local civil society and is distinct from both the state and the market. After the Great Recession new initiatives emerged which have merged old and new grassroots movements and have taken advantage of all the accumulated knowledge of older local initiatives. Moreover, the neighbourhood is home to an economically precarious but culturally important class of people; young, well-educated, politicized people with ideas that go beyond the mainstream. This class of people is playing a significant role in developing the social responses to economic hardship

Our two initiatives in Sants are Can Batlló, a former industrial complex that has been taken over by neighbours and self-managed through a cooperative approach; and the Platform for People Affected by Mortgages, which emerged in 2009 in order to address housing evictions across Spain, and is headquartered in Sants.

\subsection{Can Batlló}

Can Batlló is a 14-hectare former textile manufacturing complex which dates back to 1878 . The complex was the backbone around which the urban structure of La Bordeta's neighbourhood was organized. In its most prosperous moment it was developed as a bona fide manufacturer's town, home to more than 2000 workers. The business underpinning the manufacturing complex closed at the beginning of the 1960s. This left space for the occupation of the warehouses and workshops by various small businesses, in a transition that generated a particular industrial ecosystem. In 1976 Barcelona's General Metropolitan Plan responded to the demands of residents for public facilities and designated the land of Can Batlló as an area for public facilities and green spaces.

Since 1975, through several waves of mobilization that used various repertoires of collective 
action, the residents of Sants have been calling for a reclassification of Can Batlló as a space for green zones and public facilities. In 2009, several neighbours and social organizations launched a platform called Recuperem Can Batlló: Can Batlló és per el barri (Reclaiming Can Batlló: Can Batlló is for the neighbourhood). Various types of social collectives and organizations, such as Comissió de Veïns de La Bordeta or Centre Social de Sants, joined this platform. They established a specific date, June $1^{\text {st }} 2011$, by which they wanted public authorities to have made a decision and decided that in the absence of a decision they would occupy the complex to reclaim the space. June $1^{\text {st }} 2011$ was precisely the date on which a new conservative Mayor, Mister Xavier Trias, took office in Barcelona. The change in the City Council took place in a social climate of citizen mobilization and effervescence led by the Indignados movement. In this context, and having reached an agreement with the owner, the new Mayor decided to assign the management of part of the Can Batlló complex to the residents' platform. Specifically, Recuperem Can Batlló was granted the management of a $1,500 \mathrm{~m}^{2}$ building known as Bloc Once.

A year later, the platform Recuperem Can Batlló had renovated and transformed the Bloc Onze, creating a bar, an auditorium, a library and other spaces. Some of the resources that enabled the development of these spaces came from the City Council, but the autonomy of the management of the process was always maintained by the organization. The platform Recuperem Can Batlló is organized around an assembly that carries out monthly meetings and distributes its work throughout various commissions.

The platform also has three large projects focused on managing other spaces beyond Bloc Onze. These projects are oriented toward addressing various social challenges in the area and represent a strong belief in the potential for networks of neighbourhood associations to respond to such problems. These three large projects are: the housing cooperative La Borda, the self-managed school Arcadia, and the agency for the promotion of a cooperative and solidarity-based economy Coopolis. Each project is in fact self-organized, althoughthey maintain a relationship with the whole Can Batlló 2 initiative. These three projects are testament to the on-going nature of Can Batlló where different projects and activities are being fostered through autonomous and networked leadership. Each of these projects also has a distinct, autonomous, relationship with public authorities - according to its magnitude, scope and needs. In essence, Can Batlló is a social initiative where things are being achieved through a network of commissions and autonomous projects, each of which is horizontally managed along democratic and co-operative lines.

The holistic and integrated ambition of these communitarian initiatives, as well as the complementarity between them makes Can Batlló highly original. The platform establishes a variety of objectives in areas such as culture, basic resources, housing, and education, among others; all exhibiting different kinds of open, empowering and participative formats (Subirats \& GarcíaBernados 2015). Within the initiative a cooperativist rationale and a communitarian approach are especially significant.

Regarding relations with Barcelona City Council, the platform has accepted that issues related to the infrastructure of the spaces are addressed with the collaboration and guidance of the City Council's technical services and human and material resources. Thus, even though the platform "Recuperem Can Batllo" is conceived as an autonomous project providing services and activities beyond the state and the market, in some aspects they are willing to collaborate with public authorities in order to achieve their goals. As noted above, the platform does not own the space but has the right to use it on the basis of an agreement with the City Council. Accordingly, the platform states that it is appropriate to take advantage of the City Council's resources for the refurbishment of the spaces.

A further issue is the management agreements that imply financial collaboration between the City Council and the platform, a point that has produced intense internal debates within the platform.A culture of preserving the autonomy of civil society organizations, -something strongly rooted among many of Sants' associations - has been readily apparent with respect to Can

2 From here we will refer to 'Can Batllo' as the whole social innitiative, which embedess different social projects. 
Batlló. Until now the tendency to emphasize self-management has been maintained as a priority, always being chosen ahead of alternative options, such as co-management with public authorities. However, there is much debate on this question, with new arguments developing that may change the platform's position. In this vein, the main issue is the need to promote professionalization with respect to some of the tasks carried out in Bloc Onze. The socio-communitarian space provided over the last four years has been sustained by volunteering. However, as the project has grown to cover more space and activities, some voices have argued for professionalization, an issue that has produced strong debate within the assembly.

The profile of activists that take part in the assembly include active members of the neighbourhood movements as well as community based organizations and associations working in the area of culture, youth, schooling and collectives working in architecture. There are also many local activists involved who are committed to social movements in general and who have a strong sense of belonging to a culture of mobilisation related to self-management, communism, libertarianism, and autonomy. Without doubt, the success of the initiative can be explained by the fact that the neighbourhood has a rich and diverse associative network, but also by the capacity of the initiative to bridge differences among its diverse members through leadership practices that make cooperation possible.

Thus, old and new leaderships are combined within the platform. On one hand, Can Batlló incorporates traditional experiences developed through the neighbourhood movement. On the other hand, it also incorporates new forms of activism from the squatter movement and the cooperative movement. The fact that the taking over of the old manufacturing complex took place concurrently with the emergence of the Indignados movement produced an interesting mix of activism. That activist mix triggered a successful initiative that could be understood as a citizen response that was based on the emergence of new subjectivities taking place in the context of systemic crisis.

One of the most interesting aspects of the leadership practices of the Can Batllo platform is how they have reframed the discourse on common space. The platform was born through social networking and clearly frames Can Batlló as an alternative way to understand the city and the relationships between citizens and institutions (Subirats \& García-Bernados 2015). The management model developed in Can Batlló strives for shared decision making, evident in the desire for autonomy for the social initiative and in the valorisation of public, or collective, spaces which is implied in the platform's forms of decision making and action. The platform understands 'the public' beyond actors and agencies typically involved in public administration. This position is probably one of the most important discursive impacts of the initiative. It challenges ideas of "the public" that are deeply rooted in the Spanish collective imaginary. Instead, they hold 'the public' to be that which is recognised and defended by the community.

Nevertheless, the historical referents from which the initiative takes inspiration, and which drive socially innovative dynamics, provide a refutation to the notion that Can Batlló may be having too great an impact on the public sphere. Regarding the transferability and systematisation of the Can Batlló experience, it is important to note that the platform has done a worthwhile job of producing and spreading its own narrative. Inside the platform there have been various initiatives oriented toward disseminating what it has done and what it has achieved.

\subsection{Platform for Mortgage Affected People (PAH)}

The Platform for People Affected by Mortgage (PAH) was created in 2009 in Barcelona in response to the growing numbers of foreclosures in Spain following the bursting of the real estate bubble; a development that is still affecting hundreds of thousands of families across the country. The PAH is self-defined as a horizontal movement, non-violent, non-partisan and assembly based, which works to transform the legal framework with respect to housing rights. The original objective of the platform was to stop housing evictions but the organization has since then grown and diversified combining three main strategies of collective action: resistance, incidence 
and dissidence. They combine both contentious and conventional actions (Romanos 2013). Thus, at the same time as resisting systemic problems (such as stopping evictions or contesting public policies), they try to influence the system by proposing alternative public policies and legal reforms, as well as by producing dissident responses to the failure of authorities to address the problem.

The platform has also spread out throughout different cities of Spain through multiple autonomous local assemblies that function on a neighbourhood level. Through this process, a great growth of the platform took place rapidly since its foundation, demonstrating the success of the initiative (Romanos 2013). The PAH evolved out of an older organization called $V$ de Vivienda, that since 2006 had been campaigning for housing rights. V de Vivienda was a social movement formed by young activists engaging in acts of contestation against the real-estate bubble in many Spanish cities. The PAH founders were social activists that had a high level of education and knowledge and who did not themselves have mortgages. Essentially, they were making demands for affordable housing. We certainly cannot understand the growth of the PAH and its replication across Spain without taking into account the mix between activists and affected people that it attained in its organization. Particularly important is that affected people were empowered through the PAH and consequently became social activists themselves, not only against the mortgage injustice in Spain but also campaigning for decent housing as a social right (Mir Garcia et al. 2013). More recently the platform has also engaged tenants (rather than home-owners) at risk of eviction and evicted families in need of rehousing. This combination of a broad variety of types of people in the PAH demands leadership practices that bridge inter-class social groups. Precisely how the members of the PAH managed to engage affected people in the organization not as guilty parties but as victims who could be mobilized to help other affected people is one of the key elements that explains the success of the PAH.

The PAH not only merges activists and affected people but also different strategies of collective action (incidence, resistance, dissidence) and even different leadership practices. It is an organization for social change based on democratic and horizontal ways of getting things done. It reframes the relevant discourse, bridges differences and empowers the have-nots. But, at the same time, it also takes advantage of some charismatic individuals, such as Ada Colau. Even though the housing problem in Spain is far from solved, these different leadership practices have secured important social impacts,. As noted above, the platform has prevented thousands of evictions, has rehoused hundreds of evicted families and has helped to develop municipal regulations and even a regional law in the Catalan Parliament. The platform has also reconfigured power relations, constituting a new actor to be taken into account in housing policies and giving voice to previously unheard affected people. Thus, the PAH has empowered its members, by bridging differences between activists and affected people and unleashing their human energy. However, the main impact that the PAH has had relates to the reframing of the discourse made possible by the platform. It has redefined the housing problem, and influenced how it is understood by the majority of the population, framing it as a collective problem that goes beyond the specific circumstances of directly affected families (Flesher Fominaya 2015). The PAH has responded to a basic social need -housing- by rearticulating this need as a right.

Since 2014 the headquarters of the organization in Barcelona have been located in Sants, and since February 2015 in a street next to these same headquarters the PAH occupied an entire building, known as Bloc la Bordeta. The building is owned by SAREB, a public-private company created to take on the toxic assets of those banks saved by the national government. The PAH has occupied this building in order to rehouse 10 evicted families. For sure, this has been a crucial action in the visibilization of the presence of the PAH in the neighbourhood, and when it happened it involved the collaboration of several entities of the territory. The neighbourhood association of the area has been important in communicating the occupation to different entities of the network as well asto neighbours wanting to understand the aims of the mobilisation. Other neighbourhood initiatives promoted by organised citizens, such as as Can Batllo's platform, have also offered their help, especially regarding practical issues such as the use of tools in order to facilitate the clandestine provision of water and light supplies. 
The location of its headquarters in Sants, the decision to occupy the the Bloc la Bordeta, and the mobilisation to stop evictions in the neighbourhood evidence how active the platform is in the area. Many people affected by socially exclusionary dynamics related to housing, especially those from the most deprived areas in the district such as La Marina-Zona Franca, have been particularly supportive of the platform since its arrival to the neighbourhood. The district of Sants-Montjuïch is the second district most affected by the dynamics of foreclosures in the city of Barcelona, after the district of Nou Barris. Nonetheless, the PAH is a fairly de-territorialized initiative in the sense that it is less dependent on the neighbourhood context than the other examples of social innovation analysed in this article. Even though the PAH is most active in those neighbourhoods where the foreclosure crisis has had a significant effect, the initiative works at a city level and is better understood through its leadership practices than through the features of the neighbourhood in which it is located. In fact, the analysis suggests that as a more de-territorialized initiative that gives special attention to making political incidence the PAH achieves greater upscaling than the other initiatives analysed in this article.

Finally, focusing on the neighbourhood scale, a few more observations can be made regarding the relation between Sants and the PAH. In first place it is important to highlight the relation between the platform and one of the specific neighbourhoods of Sants: Hostalfrancs, which is traditionally a working class area with significant civic capacity in terms of socially transformative networks. This contrasts with the assumptions made by PAH's representatives regarding the relationship between the platform and the immediate territory in which they are settled[AB1]. There have been attempts to establish contact the different collectives and associations in the area, including, inter alia, neighbourhood associations, representatives from Can Batllo and Can Vies, the patriarch of the gypsies settled in the neighbourhood, as well as with officially recognised initiatives such as the "Secretariat d'entitats de Sants" (a public supported platform that tries to bring together all the civic organizations of the neighborhood). However, the acute and urgent nature of the day to day work carried out by the platform have prevented the establishment of closer relationship. PAH's representatives recognise that the creation of closer relationships with other local initiatives is necessarily a slow process. It takes time. Those associations involved in dynamics of political contestation beyond the neighbourhood, towards the city, regional or national scale have difficulties in conciliating their specific objectives with the general aim of becoming rooted in the area by linking up with other initiatives. PAH's representatives recognised that they were "snowed under" with work in this respect.

\section{Discussion}

Three main results arise from the comparison of the three embedded case studies analysed above: a) socially innovative initiatives tend to be context-dependent, meaning that we must understand the context to better comprehend the initiatives, b) despite the context, leadership practices can contribute not only to democratising socially innovative initiatives but also to multiply their impacts, and c) the nature of the relationship that a social initiative establishes with actors in higher institutional levels is a crucial factor to foster its effectiveness and its scalability.

Firstly, the historical and geographical context of a community plays a significant role in enabling or constraining the effectiveness and scalability of social innovation.

The demographic replacement in Nou Barris Nord, which was the result of the real-estate bubble, created a highly vulnerable context: a lost sense of belonging, a high rate of new-immigrant and low-income population, and significant social fragmentation. Civic capacity is weak in Nou Barris Nord for two reasons. Firstly, because, as we have already noted, its social fabric is also weak and fragmented. Secondly, because there is a lack of collaboration and coordination, not only among governmental and non-governmental actors - characterized by a hostile relationship of mistrust - but also within governmental departments and offices. In this context, 50x20 acts completely independently of public bodies, and its impact is very limited. Centre Cruï- 
1la, on the other hand, establishes relationships with community, private and governmental actors in a neighbourhood where such networks are unusual.

Sants, on the other hand, is a politicized neighbourhood with a history of social activism and a high level of civic capacity. There we found a well-connected community that has a history of collaboration with public administration, though in a context of permanent contestation. This relationship has usually been instrumental and, in general terms, no dynamics of co-option or clientelism have developed. Rather, civic capacity in Sants is a result of historical neighbourhood struggles and has been shaped through contestation, usually with the result of forcing public administrators to accept the claims of residents. At the same time, some initiatives in Sants merge old and new activisms. The role played by middle-class politicized youth in developing socially innovative responses in Sants is really significant. This is a context which provides favourable conditions for the development of social innovation. In terms of scalability, innovation takes advantage of the collaborative tradition; in terms of effectiveness, it is able to engage individuals and organizations in a problem-solving way. If we look at the initiatives that have been developed in Sants, we observe that both of them display significant levels of effectiveness and scalability.

Despite the argument that social exclusion is a catalyst of social innovation (Mac Callum et al, 2009; Moulaert et al. 2010), there is evidence from our case studies that social innovation does not necessarily occur in those neighbourhoods with the greatest social needs, but rather in those with greater civic capacity (Blanco et al., 2016). Thus, in Sants, which also have a significant tradition of political activism, we found more instances of transformative socially innovative responses than in Nou Barris Nord.

Consequently, to make social innovation a feasible alternative, community capacity building should be engaged, especially in those communities lacking resources and capacities to promote social innovation processes. Rather than focusing on specific socially innovative initiatives, we therefore suggest that policy processes should be developed at a community level to build capacity where it is lacking. This way, social innovation could emerge and be effective and scalable in any place, rather than only in those neighbourhoods with greater existing capacity.

A second insight relates to leadership practices, with the case studies revealing certain relationships between the leadership practices analysed and the effectiveness and scalability of socially innovative initiatives. Such practices are democratizing both the initiatives themselves and their outcomes.

The unleashing of human energy is a leadership practice related to the effectiveness of social innovation because it empowers citizens. We could see the effect of this in the PAH, where people affected by a particular issue are empowered not only by gaining information, knowledge and skills but also giving them a voice. Furthermore, unleashing human energy also improves the capacity of an initiative to solve the problem it aims to address, since their participants become better prepared and have more resources. The work done by Centre Cruilla training youth is also noteworthy in this respect. In both cases, specific social groups with lower resources (have-nots) are being empowered through this leadership practice.

Bridging difference is also a leadership practice that contributes to social change in very different ways. Increasing diversity and including different groups and actors usually helps to produce better solutions to social problems. Again, the PAH is a good example of how bridging different social groups - middle-class housing activists and affected people - increases the inclusiveness of the initiative. At the same time, since more and diverse groups are included in the initiative, bridging difference may also constitute a scaling out practice. This happens when the bridging practice weaves individuals and organizations within the neighbourhood into a network, as we have seen in Can Batlló, Centre Cruilla and 50x20. But it also happens when the initiative aims to be linked to society more widely. The way in whichthe PAH has evolved from a selfreferential social movement into an open platform constructed to reach a social majority shows how bridging difference contributes to scaling out. 
At the same time, bridging difference may also contribute to scaling up, especially when the bridging moves beyond the immediate initiative's neighbourhood (as is the case with Centre Cruilla and the PAH). Especially relevant in this regard is the Can Batlló case, which is disseminating its activities and approaches through various materials that are being used across the city and beyond. By summarizing and reporting on its experiences and its knowledge through transferable materials, Can Batlló is self-consciously facilitating the replication of its practices.

Finally, bridging difference usually produces a change in social relations; the practice itself is based on either establishing new relations - among social groups, individuals and/or actors - or on enhancing existing relations.

Reframing discourse is probably the leadership practice that has the greatest impact, both in terms of effectiveness and scalability. It should be noted that in Nou Barris Nord both initiatives are reactive, while in Sants the initiatives are more proactive, proposing alternative frameworks and narratives. The more reactive initiatives tend to use a pragmatic approach when they reframe their discourses. 50x20 claims that public institutions are not protecting the neighbourhood and argue that more public investment is needed. Centre Cruilla employs a frames youth inclusion in a new way, moving from a simply educational approach to a more integrated approach based on labour insertion. Initiatives that are more proactive, by contrast, usually use a political approach to reframing their discourses. At the same time, though, these initiatives link such political discourses to specific pragmatic practices at the local level. Can Batlló carries out local cultural and community activities and is launching further applied projects. However, all projects are framed according to a more general critique of the way the city has been constructed and transformed, proposing a disruptive understanding of what is 'public' and how can it be managed through an emancipatory approach. The PAH challenges public authorities' narrative around the foreclosure crises, offering an alternative as well asa completely different framework for housing policies, claiming that affordable housing is a right.

Producing new policy frames can be a way of empowering citizens, since it breaks stereotypes embedded in dominant discourses whereby some social groups are depicted as guilty of their own fate. Reframing discourse is also a practice that brings new solutions to light, either in a pragmatic or a political way, usually helping to solve the problem being addressed.

Regarding scalability, reframing discourse can have a significant impact both in terms of scaling up and scaling out. A disruptive frame can engage more people and actors, especially when it is produced in a political way. We have clearly seen this in practice with respect to the PAH, which produced an alternative narrative of crisis that changed the perception of a social majority (Flesher Fominaya 2015). When the reframed discourse links a local initiative to a broader, counter-hegemonic discourse that goes beyond the neighbourhood scale, it then becomes a useful practice for scaling up. We have observed this trend in the PAH's framing of the right to affordable housing, and the way that Can Batlló pushes for alternative urban developments. Lastly, reframing discourse is a transformative leadership practice that changes social and power relations, since it establishes counter-hegemonic narratives that re-situate and re-signify actors. At the same time, reframing discourse, together with other actions, such as engaging in advocacy or contentious politics, gives a more powerful and recognised position to some of these organizations.

Hence, unleashing human energy, bridging difference and reframing discourse have, in the course of this study, emerged as three types of democratic leadership practices that can help make social innovation effective even in those neighbourhoods with lesser capacity, such as Nou Barris Nord. Moreover, democratic leadership practices not only make social change happen, but also democratize it. Those initiatives aiming to become drivers of democratic social change should, therefore, pay attention to all three of these leadership practices.

Finally, a third explanatory factor, which is distinct from context and leadership practices though related to both, has emerged in our research as important for understanding how and when social innovation does or does not produce social change. This pertains to the relation that a socially innovative initiative, having emerged from below, establishes with actors in higher 
institutional levels (Eizaguirre et al. 2012). The effectiveness and the scalability of bottom-up initiatives are greater in those cases where they are linked to public institutions through various forms of relation and collaboration. We have seen this to be the case especially in Centre Cruilla and Can Batlló. The PAH is achieving a huge social impact. However, structural and institutional frames at national and regional levels constrain its capacity to be effective. Lastly, 50x20 shows that acting without public authorities makes it really difficult to achieve significant impacts, despite the valuable work they do.

As we have previously said, approaches that rely solely on action by traditional public institutions seem insufficient for facing the collective problems prominent in the post-recession context of austerity. Yet localized and purely grassroots initiatives do not seem to be potent enough to trigger systemic social change. There is evidence that strategies for solving contemporary social problems need to be multi-scalar; supra-local structures and agents must be accounted for, because social innovation at the local scale depends on resources that are both local and extralocal, endogenous and exogenous (Oosterlynck et al. 2013). In this context, as existing studies have stressed (Eizaguirre et al. 2012), a bottom-linked perspective appears to hold promise. This approach recognises 'the centrality of initiatives taken by those immediately concerned, but stresses the necessity of institutions that would enable, gear or sustain such initiatives through sound, regulated and lasting practices and clearer citizen rights guaranteed by a democratic state-functioning' (Moulaert et al. 2010: 9). That is to say, a bottom-linked perspective stresses the importance of initiatives that combine both top-down and bottom-up innovation; initiatives that emerge at a community level, from below, but are linked to higher-level public institutions that enable them to be effective and scalable.

\section{Conclusion}

This article has explored the nature of social change by bringing together systemic approaches on social innovation and relational theories of collective leadership. Focusing on four socially innovation initiatives in two of Barcelona's disenfranchised neighbourhoods we have documented how contextual neighbourhood features and agential leadership practices are useful variables for predicting the scalability and effectiveness of social innovation. It has been argued that both contextual neighbourhood features as well as collective leadership practices dialectically explain not only how and why social innovation initiatives emerge but also their social impact.

From our comparative case-study analysis we identify three main strategies in order to foster genuinely transformative social innovation initiatives: building community capacities at neighbourhood level, developing democratic leadership practices (unleashing human energies, bridging differences and reframing discourse) and developing what some scholars call a "bottomlinked" approach. A multi-scalar and comprehensive combination of these three strategies seems to be required for social innovation to become a real driver of social change.

\section{References}

Atkinson, R. \& Kintrea, K., 2001. Disentangling area effects: Evidence from deprived and nondeprived neighbourhoods. Urban Studies, 38(12), pp.2277-2298.

Bauman, Z., 1999. Modernidad líquida, Buenos Aires: Fondo de Cultura Económica.

Beck, U., 1992. Risk Society: Towards a New Modernity, Cambridge: Polity Press.

Blanco, I. \& Leon, M., 2013. Who's the containment dike? The Spanish Mortgage Victims Platfor (Plataforma de Afectados por la Hipoteca - PAH) as a driver of social innovation. In Interrogating Urban Crisis: Governance, Contestation and Critique. Leicester: De Montfort University.

Blanco, I., \& León, M., 2016. Social innovation, reciprocity and contentious politics: Facing the socio-urban crisis in Ciutat Meridiana, Barcelona. Urban Studies . https://doi.org/ 10.1177/0042098016659044

Davies, J. \& Pill, M., 2012. Empowerment or Abandonment? Prospects for Neighbourhood Revitalization under the Big Society. Public Money and Management, 32(3), pp.193-200. 
Eizaguirre, S., Pradel, M., Terrones, A., Martinez-Celorrio, X., \& Garcia, M. (2012). Multilevel Governance and Social Cohesion: Bringing Back Conflict in Citizenship Practices. Urban Studies, 49(9), pp.1999-2016.

Flesher Fominaya, C., 2015. Redefining the Crisis/Redefining Democracy: Mobilising for the Right to Housing in Spain's PAH Movement. South European Society and Politics, 20(4), pp.465-485.

Fregonese, S., 2013. Mediterranean geographies of protest. European Urban and Regional Studies, 20(1), pp.109-114.

Giddens, A., 1999. Consecuencias de la modernidad, Madrid: Alianza.

Gualini, E., Mourato, J.M. \& Allegra, M., 2016. Conflict in the City Contested Urban Spaces and Local Democracy, Berlin: Jovis.

Heifetz, R.A., Grashow, A. \& Linsky, M., 2009. The practice of adaptive leadership: tools and tactics for changing your organization and the world, Cambridge: Harvard Business Press.

Leon, M. \& Pavolini, E., 2014. "Social Investment" or Back to "Familism": The Impact of the Economic Crisis on Family and Care Policies in Italy and Spain. South European Society and Politics.

Lowndes, V. \& Pratchett, L., 2012. Local Governance under the Coalition Government: Austerity, Localism and the "Big Society." Local Government Studies, 38(1), pp.21-40.

MacCallum, D. et al., 2009. Social innovation and territorial development, Farnham: Ashgate.

Mir Garcia, J. et al., 2013. Fonaments de la Plataforma d'Afectats per la Hipoteca: activisme, assessorament col.lectiu i desobediencia civil no violenta. Educacio Social. Revista d'Intervencio Socioeducativa, (55), pp.51-60.

Moulaert, F. et al., 2010. Can Neighbourhoods Save the City?, New York: Routledge.

Moulaert, F. et al., 2013. The International Handbook On Social Innovation, Northampton, MA: Edward Elgar.

Moulaert, F., Jessop, B. \& Mehmood, A., 2016. Agency, structure, institutions, discourse (ASID) in urban and regional development. International Journal of Urban Sciences, 5934(May), pp.1-21.

Oosterlynck, S. et al., 2013. The butterfly and the elephant : local social innovation, the welfare state and new poverty dynamics,

Ospina, S., 2006. Gobernanza y liderazgos para el cambio social. Revista del CLAD. Reforma y Democracia., (35), pp.93-122.

Ospina, S. et al., 2012. Social Change Leadership as Relational Leadership. In M. Uhl-Bien \& S. M. Ospina, eds. Advancing Relational Leadership Research. A dialogue Among Perspectives. Charlotte, NC: Information Age, pp. 255-302.

Ospina, S. \& El Hadidy, W., 2013. How Social Change Organizations Create Leadership Capital and Realize Abundance amidst Scarcity, New York.

Parés, M.; Boada, J.; Canal, R.; Hernando, E.; Martínez, R., 2017. "Challenging collaborative urban governance under austerity: how local governments and social organizations deal with housing policy in Catalonia (Spain)" Journal of Urban Affairs. DOI: $10.1080 / 07352166.2017 .1310531$

Parés, M.; Ospina, S.; Subirats, J., 2017b. Social Innovation and Democratic Leadership. Communities and Social Change from Below. Chentelham: Edward Elgar Publishing.

Peck, J., 2012. Austerity urbanism. City, 16(6), pp.626-655.

Romanos, E., 2013. Evictions, Petitions and Escraches: Contentious Housing in Austerity Spain. Social Movement Studies: Journal of Social, Cultural and Political Protest, (September).

Stone, C.N., 2001. Civic Capacity and Urban Education. Urban Affairs Review, 36(5), pp.595619.

Subirats, J. \& García-Bernados, Á., 2015. Innovacion social y políticas urbanas en España. Experiencias significativas en las grandes ciudades, Barcelona: Icaria.

Swyngedouw, E., 2015. Urban Insurgencies and the re-politicization of the unequal city. In F. Miraftab, D. Wilson, \& K. Salo, eds. Cities and Inequalities in a Global and Neoliberal World. New York: Routledge, pp. 173-187.

Uhl-Bien, M. \& Ospina, S., 2012. Advancing Relational Leadership Theory: a Conversation among Perspectives, Charlotte, NC: Information Age.

Walliser, A., 2013. New urban activisms in Spain: reclaiming public space in the face of crises. Policy \& Politics, 41(3), pp.329-350. 


\section{Aknowledgments}

The results of the fieldwork presented in this article are part of a research project called SOCRISIS Social Innovation Against the Crisis: How leadership practices and civic capacity improve neighbourhood development (www.socrisis.net) which has been framed in the EU Marie Curie Programme. 
Table 1. Analysed neighbourhoods

\begin{tabular}{|l|l|c|c|c|c|c|}
\hline & \multicolumn{5}{|c|}{ Sants } & \multicolumn{3}{c|}{ Nou Barris Nord } \\
\hline & & $\mathbf{2 0 0 8}$ & $\mathbf{2 0 1 4}$ & & $\mathbf{2 0 0 8}$ & $\mathbf{2 0 1 4}$ \\
\hline Population & & 59.881 & 59.550 & & 14.585 & 14.062 \\
\hline Surface (Km $\left.{ }^{2}\right)$ & & 1,7 & 1,7 & & 2,8 & 2,8 \\
\hline Density (hab/Km $\left.{ }^{2}\right)$ & & 35.224 & 35.029 & & 5.209 & 5.022 \\
\hline $\begin{array}{l}\text { Available Family } \\
\text { Income Index } \\
(\text { Barcelona = 100) }\end{array}$ & Sants & 87,1 & 85,8 & Torre Baró & 62,1 & 45,6 \\
\cline { 2 - 8 } & $\begin{array}{l}\text { La } \\
\text { Bordeta }\end{array}$ & 80,8 & 76,0 & $\begin{array}{l}\text { Ciutat } \\
\text { Meridiana }\end{array}$ & 58,8 & 39,2 \\
\cline { 2 - 8 } & & & & Vallbona & 59,6 & 39,9 \\
\hline
\end{tabular}

Source: Ajuntament de Barcelona 